\title{
UJGURSKIE DZIEDZICTWO KULTUROWE W STARCIU Z CHIŃSKĄ REPUBLIKĄ LUDOWA
}

\author{
UYGHUR CULTURAL HERITAGE IN THE CLASH \\ WITH THE PEOPLE'S REPUBLIC OF CHINA
}

\begin{abstract}
The main intention of this article is an attempt to answer the question of how the Sino-Uyghur relations affect the cultural heritage of Muslim Uyghurs? The author devoted special attention to the issue of Uyghur ethnic consciousness, which at some stage differentiated the Uyghurs from Chinese civilization. An important part of the work is also an analysis of the contemporary situation in Xinjiang and the problem of growing Uyghur radicalism. A summary of the considerations concerns the analysis of the mechanisms driving the conflict and possible solutions.
\end{abstract}

Key words: ethnogenesis; cultural heritage; separatism; extremism; Uyghur; Xinjiang; China; Central Asia

Streszczenie

Artykuł podejmuje próbę odpowiedzi na pytanie, w jaki sposób relacje chińsko-ujgurskie rzutują na kulturowe dziedzictwo muzułmańskich Ujgurów? Szczególną uwage autorka poświęca zagadnieniu etnicznej świadomości Ujgurów, która na pewnym etapie rozwoju zróżnicowała Ujgurów od chińskiej cywilizacji. Ważną część pracy stanowi również analiza współczesnej sytuacji w Xinjiangu oraz problemu narastającego ujgurskiego radykalizmu. Podsumowanie rozważań dotyczy analizy mechanizmów napędzających konflikt i możliwości jego rozwiązania.

NATALIA JUSTYNA SIENKO Uniwersytet Wrocławski, Wrocław E-mail: natalia.s1993@wp.pl

CITATION: Sienko, N. J. (2018). Ujgurskie dziedzictwo kulturowe w starciu z Chińską Republiką Ludową. Sprawy Narodowościowe. Seria nowa, 2018(50). https://doi.org/10.11649/sn.1567

Słowa kluczowe: etnogeneza; dziedzictwo kulturowe; separatyzm; ekstremizm; Ujgurzy; Xinjiang; Chiny; Azja Centralna

This work was supported by the author's own resources. No competing interests have been declared.

This is an Open Access article distributed under the terms of the Creative Commons Attribution 3.0 PL License (creativecommons.org/licenses/by/3.0/pl/), which permits redistribution, commercial and non-commercial, provided that the article is properly cited. (C) The Author(s) 2018.

Publisher: Institute of Slavic Studies, Polish Academy of Sciences 
$\mathrm{O}$ bszar, który współcześnie zamieszkują Ujgurzy, czyli największy autonomiczny region Chin Sinciang-Ujgur, nazywany zamiennie Xinjiangiem/Ujguristanem/ Wschodnim Turkiestanem (autorka będzie się posługiwać terminem „Xinjiang”, który w największym stopniu odpowiada współczesnej oficjalnej nazwie "Xinjiangzizhiqu") stanowi prawie 1/6 terytorium Chińskiej Republiki Ludowej. Obecnie graniczy z ośmioma państwami oraz sąsiaduje z trzema imperialnymi mocarstwami - Chinami, Rosją i Indiami. Dodatkowy walor regionu stanowi również bogactwo zasobów naturalnych oraz suchy klimat, dzięki któremu zachowały się ślady starożytnej świetności kulturowego dziedzictwa Ujgurów. Między innymi ze względu na strategiczne położenie geograficzne Xinjiangu usytuowanego w obrębie starożytnego szlaku handlowego, łączącego Wschód z Zachodem, grecko-rzymską cywilizację z kulturą buddyjską oraz Azję Środkową ze Wschodnią do dnia dzisiejszego trwa wieloletni spór między największą grupą zamieszkującą Xinjiang - Ujgurami a Chińczykami Han (Kamberi, 2005, ss. 1-2). Niekończąca się historia chińsko-ujgurskiej walki i przemocy w coraz większym stopniu odciska dramatyczne piętno na kulturowym dziedzictwie muzułmańskich Ujgurów, w szczególności architekturze perły Jedwabnego Szlaku - Kaszgarze. Mordowana i torturowana, bezsilna wobec społecznej marginalizacji i utraty spuścizny kulturowej tureckojęzyczna grupa etniczna, sięgając coraz częściej po radykalne metody, naraża się tym samym na narastające prześladowania ze strony Chin.

W niniejszej pracy autorka pragnie wyjaśnić mechanizmy napędzające wielopłaszczyznowy konflikt. Głównym zamierzeniem pozostaje próba odpowiedzi na pytanie, w jaki sposób relacje chińsko-ujgurskie rzutują na kulturowe dziedzictwo muzułmańskich Ujgurów? Szczególnej analizie zostanie poddana etnogeneza Ujgurów jako proces, który skutecznie zróżnicował największą mniejszość zamieszkującą współczesny Xinjiang. Autorka zwróci uwagę również na skalę makro, czyli kraje potencjalnie zaangażowane w konflikt, bądź mogące odnieść się W sprawie.

\section{ŚWIADOMOŚĆ UJGURÓW - GENEZA KONFLIKTU CHIŃSKO-UJUGRSKIEGO}

Pierwsze wzmianki o Ujgurach pojawiają się już w chińskiej historiografii z III w. n.e., kiedy starożytne plemię tureckojęzyczne najprawdopodobniej od pierwszych wieków naszej ery pielęgnowało kulturową tradycję (China: Situation of Uyghurs, 2016, s. 4). Problem z określeniem jednoznacznej etnogenezy Ujgurów wynika z ich złożonych powiązań z wieloma przodkami - „Di”, „Chidi”, ,Xiongnu”, „Dingling” i "Gaoche” oraz prowadzonego koczowniczego trybu życia (Kamberi, 2015, s. 2). Wiadome jednak, że pojawili się oni w Azji Centralnej wraz z zanikiem ludów indoeuropejskich, m.in. Sogdyjczyków i Tocharów, przy jednoczesnym wzroście znaczenia ludów tureckich oraz nieprzerwanej obecności Chin (Gil, 2016, s. 294). W porównaniu do innych ludów Ujgurzy już w VII w. odgrywali wiodącą rolę w Azji Centralnej oraz prowadzili rozwinięte życie kulturowo-polityczne, zaś w latach 40. VII wieku, obalając lokalnych władców, utworzyli Pierwszy Kaganat Ujgurski na terenach dzisiejszej Mongolii, części Mandżurii i Dżungarii oraz współczesnego Xinjiangu (Bazylow, 1981, s. 47). Pierwszy Kaganat podbity przez odradzający się turecki Kaganat Wschodni wymusit migrację plemion na terytorium Chińskiego Cesarstwa rzą- 
dzonego przez dynastię Tang (Gil, 2016, s. 295). Warunki klimatyczne tego regionu oraz pozytywne relacje z dynastią Tang, która upatrywała w Ujgurach możliwość stanowienia bariery ochronnej oraz dostrzegała ich potencjał handlowy, pozwoliły początkowo osiedlić się na tym obszarze (Tyler, 2004, s. 44).

W 847 r. Drugi Ujgurski Kaganat podbili Kirgizi, co wymusiło na ludności konieczność oddalenia się od Doliny Orkhon i przesiedlenia na południe, południowy zachód oraz tereny zachodnie, by ponownie zasiedlić obszar współczesnego Turkiestanu Wschodniego. W chińskiej historiografii wspomina się o utworzeniu w kolejnych latach małych, niezależnych ujgurskich państewek - Karachanidów ze stolicą w Kaszgarze (950 - 1212 r.) i Turfan (866 - 1369) oraz objęciu terenów prowincji Gansu (847 - 1036). Historyczne dane świadczą również o niebagatelnej roli, którą odgrywali Ujgurzy w zachodniej części Chin. Dzięki położeniu geograficznemu kontrolowanych regionów stali się mediatorami między chińskimi a indoeuropejskimi kupcami, pośrednicząc w wymianie handlowej na obszarze szlaków prowadzących z Chin do Morza Kaspijskiego (Дергачев, b.d.; Турсун, b.d., ss. 4-5).

Pomimo niepodważalnej, historycznej obecności Ujgurów na obszarze dzisiejszego autonomicznego regionu Xinjiangu, stanowiącego kolebkę ujgurskiego dziedzictwa kulturowego, w źródłach chińskiej historiografii oraz badaniach prowadzonych w XX w. istnieje wiele sprzeczności, dotyczących etnogenezy Ujgurów. O ile istnieją wiarygodne źródła opisujące rozwinięte etniczno-polityczne czy duchowe życie ludu oraz pochodzące z wczesnośredniowiecznego okresu ujgurskie budowle, rękopisy czy dowody zebrane w trakcie wykopalisk archeologicznych, nie są one traktowane przez chińskich badaczy jako jednoznaczne potwierdzenie ujgurskiego zasiedlenia Xinjiangu przed chińskimi dynastiami. Zdaniem Су Бэйхай (transkrypcja: Su Béjhaj.) za rdzenną ludność tych obszarów należy uznać Chińczyków Han, którzy przybyli na zachodnie tereny Chin przed tureckimi ludami, o czym świadczy chociażby Zamek Taszkurgan (zarówno chińska wyprawa w stronę Xinjiangu z 138 r. p.n.e., jak i późniejsza ekspedycja z rozkazu cesarza Wu pochodzącego z dynastii Han nie podporządkowała sobie eksplorowanych terenów z powodu niesprzyjających warunków naturalnych oraz skutecznych ataków koczowniczych Hunów; Olechowski, 2012, s. 308; Турсун, b.d., s. 13). Bardziej współcześnie Chińczycy Han dokonywali jednak kolonizacji tych obszarów dopiero w XVIII w. po podboju przez niechińską, ale mandżurską dynastię Qing. Kontrowersje wokół etnicznego pochodzenia Ujgurów oraz historycznego prawa do kontrolowania Xinjiangu nie wynikają tylko i wyłącznie z braku wiarygodnych źródeł z okresu przypadającego na pojawienie się Ujgurów w Azji Centralnej oraz późniejszego założenia Pierwszego Kaganatu Ujgurskiego, lecz są konsekwencją wieloletniej politycznej sytuacji Turkiestanu Wschodniego. Nie ulega jednak wątpliwości, że warunki, w jakich przyszło żyć starożytnym Ujgurom, kwestie genetycznego podobieństwa do ludów tureckich, wieloetniczne doświadczenia, a w dodatku dyskryminacyjna polityka chińskich władz, doprowadziły do zupełnego zróżnicowania Ujgurów w stosunku do chińskiego wroga. Współcześni Ujgurzy różnią się zatem od Chińczyków Han religią, wyznając islam (zdecydowana większość Ujgurów jest zwolennikami jednej z najbardziej liberalnej sunnickiej szkoły hanafickiej, popularnej również wśród wyznawców z Turcji i Azji Centralnej. Radykalizm wśród Ujgurów wynika zatem z próby przeciwdziałania ograniczeniu praw religijnych czy kulturowych; Hudayar, 2017), językiem zapisywanym najczęściej alfabetem arabskim w redakcji perskiej (język ujgurski wywodzi się z języka wschodniotureckiego oraz czagatajskiego. Oprócz alfabetu arabskiego Ujgurzy zamieszkujący Azję Centralną korzystają z cyrylicy. W diasporach posługują się także 
alfabetem arabskim. Hamut \& Joniak-Lüthi, 2015), zwyczajami czy materialnym dziedzictwem kulturowym, m.in. niską zabudową ujgurskich domów w kolorze piasku pustyni (Repetowicz, 2015; Турсун, b.d., ss. 10-13). Jednak zdaniem Alicji Bachulskiej paradoks obecnie utrzymujących się nastrojów separatystycznych polega na tym, że historyczna samoidentyfikacja Ujgurów charakteryzowała się tzw. tożsamością oaz, co oznacza, iż wynikała z poczucia przynależności do innych lokalnych plemion. Inną przeszkodą w naturalnym krystalizowaniu się świadomości narodowej były miejscowe podziały oraz ambicje sąsiednich mocarstw. W związku z tym ujgurskiego nacjonalizmu nie scaliła sama w sobie unikatowa tożsamość wykształcona na pewnym etapie rozwoju, a próba przeciwdziałania chińskiej polityce asymilacji oraz sprzeciw wobec traktowania Ujgurów jako obywateli drugiej kategorii (Bachulska, 2015).

Nie można nie zgodzić się z powyższym stanowiskiem z uwagi na fakt zanikania świadomości istnienia starożytnego ludu Ujgurów, zastępowanej z jednej strony poczuciem współuczestnictwa w świecie islamu, zaś z drugiej regionalną przynależnością do Kaszgarów, Tufańczyków czy etnograficzną do Taranczów (Gil, 2016, s. 302). Szczególnie proces islamizacji ludności ujgurskiej przyczynił się do wyjścia z użycia historycznego terminu Uyghur aż do XIX w., kiedy nazwa została ponownie rozpowszechniona przez tureckich mówców. Inne dane świadczą jednak o tym, iż w trakcie konferencji w Taszkencie w 1921 r. sowieccy decydenci, przywołując etykietę Uyghura doprowadzili do ożywienia identyfikacji etnicznej, aby zapobiec pantureckiej rewolucji (China: Situation of Uyghurs, 2016, s. 5). W związku z tym uzasadnione pozostaje przekonanie o zmieniającej się na przestrzeni lat samoświadomości Ujgurów, budowanej szczególnie w momentach konieczności zaakcentowania ich opozycji w stosunku do innych grup.

Błędnym byłoby jednak uznanie, że znaczenie ujgurskiej tożsamości w konflikcie chińsko-ujgurskim odgrywało marginalną rolę. Sama rozbieżność interesów, wynikających z odrębnego pochodzenia etnicznego umożliwia zakwalifikowanie wieloletnich napięć chińsko-ujgurskich do konfliktów etnicznych, szczególnie doskwierających państwom wielonarodowym. Należałoby cofnąć się do wydarzeń mających miejsce w XVIII w. by zauważyć, że początkowe poczucie etnicznej odrębności nie pozwoliło zidentyfikować się z dynastią Qing, która również dostrzegając kulturowe, językowe i religijne różnice podejmowała radykalne działania wobec „obcych”. W konsekwencji prowadzonej polityki monokulturowości chińska historiografia często traktuje Ujgurów jako „część składową chińskiego narodu" (Bovingdon, 2010, s. 28). Dlatego właśnie w dalszej perspektywie odrębna tożsamość była motorem napędowym dla ujgurskich form oporu, podobnie przeciwko mandżurskiej kontroli Turkiestanu Wschodniego w XVIII w., jak i współcześnie. Za jedno ze źródeł konfliktu można zatem uznać różnice kulturowe pomiędzy muzutmańskimi Ujgurami oraz Chińczykami Han, mając również na względzie wieloaspektowe podłoże problemu.

Okres związany bezpośrednio z konfliktem chińsko-ujgurskim przypada szczególnie na połowę XVIII W., kiedy ekspansja mandżurskiej dynastii Qing osiągnęła punkt kulminacyjny, opanowując Dżungarię oraz roszcząc sobie prawo do pozostającego pod kontrolą Chaganatu Dżungarskiego Turkiestanu Wschodniego. W związku z tym do 1760 r. Turkiestan Wschodni został przekształcony w chińską prowincję Sinkiang Xinjiang (Ануфриев, 2013, ss. 154-155). Ujgurzy niezadowoleni z obowiązującego stanu rzeczy, często pogardzani przez mandżurską dynastię, doprowadzili do serii powstań, lecz początkowo nie proklamowali niepodległości. Dopiero w 1933 r. utworzono I Republikę Turkiestanu Wschodniego, która przetrwała zaledwie kilka miesięcy. Kolejny okres funkcjonowania niepodległego 
państwa przypada na lata 1944-1949, kiedy przy wsparciu Związku Radzieckiego powstata II Republika Turkiestanu Wschodniego. Od 1955 r. Xinjiang pozostaje Regioniem Autonomicznym Sinciang-Ujgur, choć status terytorium ma współcześnie niewiele wspólnego z rzeczywistą autonomią (China: Situation of Uyghurs, 2016, ss. 11-12; Gil, 2016, s. 299; Wieczorek, 2015, ss. 11-12).

\section{ŻYCIE WE WSPÓtCZESNYM XINJIANGU}

Jak zauważa Zbigniew Kobyliński: „dziedzictwo kulturowe jest zasobem ograniczonym, nieodnawialnym i narażonym na zniszczenie". I właśnie te cechy czynią go niezwykle cennym dla każdej grupy etnicznej czy narodu. Bezpieczeństwo kulturowe wiąże się zatem z ochroną materialnego oraz niematerialnego dziedzictwa, na które składa się architektura, dzieła sztuki, książki, zwyczaje, język czy wartości duchowe. Wszystkie te elementy traktuje się jako świadectwo istnienia danej grupy. W procesie identyfikacji dobra mające wartość historyczną, naukową czy kulturową pozwalają odróżnić jedną grupę od drugiej, dzięki czemu w naturalny sposób umacniają etniczną czy narodową tożsamość i stanowią ważne jej oznaki przekazywane z pokolenia na pokolenie (Kobyliński, 2011, ss. 21-24).

Przypadek Ujgurów żyjących we współczesnym Xinjiangu pozostaje o tyle trudny, iż wieloletnia dyskryminacyjna polityka oraz systematyczna etniczna marginalizacja z roku na rok staje się coraz bardziej skuteczna, rzutując na kulturowe dziedzictwo muzułmańskich Ujgurów. Kwestia, która szczególnie podnosi debatę na temat okoliczności zacierania tradycyjnej kultury ujgurskiej dotyczy znaczącej zmiany w strukturze ludności Xinjiangu. W 1949 r. Ujgurzy stanowili 90\% ludności regionu, a w 2013 r. region zamieszkiwało ich tylko 10,52 mln (47,1\%) przy wzrastającej liczbie Chińczyków Han (37,9\%) (do pozostałych mieszkańców Xinjiangu należy ludność pochodzenia tureckiego - Kazachowie, Kirgizi, Uzbecy oraz inni wyznawcy islamu - ludy turkijskojęzyczne, Chińczycy Hui; Weiwen, 2014, s. 15). Sprawa pozostaje o tyle niepokojąca, iż do tej pory grupa, która stanowiła większość, obecnie na skutek polityki sinizacji, czyli zasiedlania Hanów w Autonomicznym Regionie Sinciang-Ujgur poddawana jest stopniowej pacyfikacji. Ze względu na społeczną i ekonomiczną dominację Hanów, tożsamą w tym przypadku z dyskryminacją Ujgurów na rynku pracy, potomkowie tubylczych plemion z Azji Centralnej coraz chętniej opuszczają autonomiczny region, osiedlając się w Azji Środkowej, na Bliskim Wschodzie, Turcji, a także Europie czy Ameryce Północnej. Spore diaspory zamieszkują Kazachstan, Kirgistan czy Uzbekistan, co wynika m.in. z faktu kulturowej bliskości, której na próżno szukać pomiędzy Ujgurami a Chińczykami Han (Hudayar, 2017; Мавлонова, 2015, s. 169).

Wiadomo również, iż wraz ze stale wzmacniającą się pozycją ekonomiczną i ekspresją kulturową Hanów, słabnie położenie pozostałych mniejszości narodowych (m.in. ludności pochodzenia tureckiego), które podobnie jak Ujgurzy napotykają trudności w znalezieniu pracy zarobkowej czy dostępie do usług socjalnych, lecz na pewno nie w stopniu odpowiadającym omawianej w niniejszym artykule grupie etnicznej. Co ciekawe, zarówno władze, jak i pozostali mieszkańcy Xinjiangu wykazują pozytywny stosunek do kilkutysięcznej rosyjskojęzycznej społeczności. Ta chętnie asymilująca się mniejszość, w przeciwieństwie do Ujgurów, nie protestuje m.in. przeciwko nauce języka chińskiego w szkołach (China's changing strategic concerns..., 2006, s. 5; Ротарь, 2011). 
Z tego też względu opór wobec sinizacji wzmaga chińskie działania zmierzające do spadku znaczenia języka ujgurskiego w sferze publicznej. Od powstania Chińskiej Republiki Ludowej wprowadzona została polityka „dwujęzycznej edukacji”, stopniowo eliminująca język ujgurski w regionie Xinjiangu na rzecz nauczania mandaryńskiego. Niekiedy Ujgurzy również dobrowolnie rezygnują z edukacji w ojczystym języku z uwagi na własne bezpieczeństwo oraz rynek pracy, wymagający znajomości putonghua (mandaryńskiego). W 2006 r. chiński rząd obiecał rodzicom posyłającym do szkół dzieci dotacje finansowe w przypadku wyboru programu nauczania mandaryńskiego (Uyghur Language Under At tack: The Myth of "Bilingual" Education in the People's Republic of China, 2007, ss. 1-3; $\mathrm{Wu}, 2006)$

Warta uwagi pozostaje również sprawa chińskiej antyreligijności i dyskryminacji religijnej muzułmańskich Ujgurów, co przejawia się w zakazach czytania Koranu, przestrzegania Ramadanu czy noszenia brody u mężczyzn i hidżabu wśród kobiet. Ponadto w Xinjiangu zamyka się miejsca kultu religijnego, które uprzednio także rujnuje (Bhattacharji, 2012). Współcześnie niepokojący pozostaje również problem niszczenia kilkusetletniej tradycyjnej architektury ujgurskiej. Do tej pory szczególnie zdewastowano większość zabytków starego miasta w Kaszgarze, a tam, gdzie Chińczycy odnaleźli sposób na zysk finansowy, postanowiono wprowadzić opłaty za wejście do zabytkowych stref, co w ramach zwiedzania „żywego muzeum” może objąć również wspólny positek z ujgurską rodziną (magda, 2010). Dodatkowo w 2009 r. wszedł w życie plan określony jako „Likwidacja niebezpiecznych budowli w Kaszgarze", na którego realizację przeznaczono 500 mln dolarów. Rzeczywisty zamiar urbanistycznej reformy polega jednak na wyburzeniu 85\% tradycyjnej zabudowy starożytnego miasta wpisanego na listę Światowego Dziedzictwa UNESCO na rzecz nowoczesnych bloków mieszkalnych oddanych do użytku Chińczykom Han (Parlament Europejski w 2011 r. wydał w sprawie dewastacji Kaszgaru rezolucję, w której nakazał renowację miejskich zabytków w ramach ochrony dziedzictwa kulturowego. Sam fakt jej publikacji dwa lata po przyjęciu przez Chiny „programu odbudowy” wskazuje na nieskuteczność przyjętego dokumentu, podobnie jak poprzednich rezolucji mających wspomóc ochronę praw człowieka w Chinach. Rezolucja Parlamentu Europejskiego z dnia 10 marca 2011 roku w sprawie sytuacji i dziedzictwa kulturowego w Kaszgaru, 2011). Nie ulega zatem wątpliwości, że rządowe plany przesiedlania Hanów w okolice starego miasta, nieodwracalnie zniszczą ujgurski ośrodek kultury. Pekin tworząc na terenie Xinjiangu samowystarczalne osiedla, budując metodycznie drapacze chmur oraz rozwijając infrastrukturę drogową, obiecuje Hanom korzystne warunki mieszkalne i dobrze płatne miejsca pracy. Dziś puste dzielnice na przestrzeni lat zostaną zapełnione ludnością, która rozpocznie migrację z terenów przeludnionych. Mixed sand, czyli "mieszanie piasku", doprowadzi do stopniowej asymilacji terytorialnej i etnicznej oraz zaniku tradycyjnej ujgurskiej architektury (Finley, 2013, ss. 28-29).

Wysokie bezrobocie wśród Ujgurów w regionie Xinjiangu (szczególnie osób z wyższym wykształceniem oraz ludności skoncentrowanej w obszarach wiejskich) wynika z dyskryminacji mniejszości etnicznych w zatrudnieniu. W związku z tym, że ok. 15-17\% ujgurskich absolwentów uniwersytetów znajduje pracę, coraz mniej osób decyduje się uzyskać wyższe wykształcenie. Sytuację skomplikowały wydarzenia z 2009 r., kiedy po zamieszkach w Urumqi niektóre z firm wprowadzity zakaz zatrudniania Ujgurów. Inną kwestią pozostaje fakt, iż finansowe dotacje na inwestycje rządowe przydzielane są położonemu na północy najbardziej zurbanizowanemu regionowi Xinjiangu, co zwiększa nierówność gospodarczą i oddala bogatą północ od biednego, nieuprzemysłowionego połu- 
dnia, zamieszkiwanego w dużej mierze przez Ujgurów. Ubóstwo wynikające z nadwyżki siły roboczej na południu Xinjiangu i brak perspektyw na poprawę obecnej sytuacji zmusza ludność do zachowań przestępczych, a coraz częściej separatystyczne dążenia regionu mają charakter terrorystyczny (Tohti, 2015).

Kiedy medialny wizerunek tybetańskich buddystów reprezentowanych przez Dalajlamę przybrał miano pokojowych i tolerancyjnych dyplomatów, chcących przywrócić w Tybecie stabilizację; Ujgurów wyznających islam kreuje się jako osoby chętnie zasilające szeregi Państwa Islamskiego (ISIS) i tym samym współwinnych trwania "globalnej wojny z terroryzmem" (Shan \& Chen, 2009, s. 15). Nie można jednak nie zgodzić się, że brak silnego przywódcy i bierność społeczności międzynarodowej skłania młodych, ubogich Ujgurów do współpracy z islamskimi ekstremistami. Do pierwszych ataków dokonywanych na chińskim rządzie przez Islamski Ruch Wschodniego Turkiestanu (East Turkestan Islamic Movement - ETIM) dochodziło już w latach 90. Uznana w 2002 r. za organizację terrorystyczną, grupa zgodnie z przedstawionymi przez Pekin danymi, powiązana została z pakistańskimi talibami i innymi bojownikami, aktywnymi wzdłuż granicy z Afganistanem. Niemniej jednak od czasu powstania ETIM Pekin najprawdopodobniej zawyżał liczby dokonywanych ataków, aby dołączyć do państw walczących z międzynarodowym terroryzmem, a przy okazji eliminując ujgurski separatyzm (ETIM w 2012 r. nie został wymieniony jako organizacja terrorystyczna na zaktualizowanej liście Departamentu Stanu USA. Bhattacharji, 2012).

Pomimo tego, że do przemocy między Ujugrami a Hanami dochodziło od kilkuset lat, społeczność międzynarodowa zwróciła uwagę na konflikt dopiero po wspomnianych zamieszkach w największym mieście Xinjiangu - Urumqi. W 2009 r. w wyniku demonstracji śmierć poniosło prawie 200 osób. Bezpośrednie wydarzenia, które doprowadziły do manifestacji kilku tysięcy Ujgurów były związane z oskarżeniem Ujgurów o gwałt na Chince w prowincji Guangdong pod koniec czerwca 2009 r. W odwecie Chińczycy zabili dwóch Ujgurów, co przyczyniło się do krwawych zamieszek, w oddalonym od prowincji Urumqi (Shan \& Chen, 2009, ss. 14-15; Szyszlak, 2012, ss. 177-179). Opisywane wydarzenia na tyle wstrząsnęły członkami Komunistycznej Partii Chin, że po prawie roku od wydarzeń z Urumqi partia przedstawiła plan rozwoju Xinjiangu do roku 2020, obiecując przeznaczyć na rozwój gospodarczy oraz poprawę warunków życia w wieloetnicznym regionie setki miliardów yuanów, jednakże z perspektywy czasu zapowiedziane reformy nie przyniosły wymiernych rezultatów, a wręcz przeciwnie - pogłębiły lukę gospodarczą pomiędzy północą a południem oraz zwiększyły napływ Hanów na zurbanizowane obszary (Shan \& Chen, 2010, s. 59).

Od 2009 r. w Xinjiangu systematycznie dochodzi do ataków zorganizowanych przez Ujgurów. W 2011 r. doszło do ataków w Kaszgarze, gdzie życiem przypłaciło je dziesiątki tysięcy osób. W 2013 r. na Placu Tiananmen ujgurski separatysta wjechał samochodem w tłum ludzi, uśmiercając 40 osób. W następnym roku w Kunming miał miejsce atak na dworzec kolejowy, w wyniku którego zmarło 29 osób. W maju 2014 r. zginęło 31 osób, a 90 zostało rannych po rozbiciu dwóch samochodów w restauracyjnej części Urumqi. Jednak do najkrwawszego incydentu od czasu manifestacji z 2009 r. doszło w wyniku napaści na posterunek policji i chińskie urzędy w lipcu 2014 r., kiedy śmierć poniosło prawie 100 osób. Według informacji chińskich służb zamachem kierował Nuramat Sawut, będący członkiem ETIM („Uighur exiles confirm deaths in China clash”, 2014). Jednym z ostatnich ataków w 2016 r. była przeprowadzona przez zamachowca samobójcę napaść na ambasadę Chin w stolicy Kirgizji, Biszkeku. W wyniku wybuchu samochodu pułapki rannych zostało 3 pracowników ochrony (Phillips, 2016). 
Sytuacja na najbliższe lata nie wygląda optymistycznie. Raport opublikowany w 2016 r. przez think thank New America jednoznacznie potwierdza udział 114 Ujgurów w strukturach dżihadu na 118 fundamentalistów pochodzących z Chin (Campbell, 2016). Za uwierzytelnienie informacji dotyczących nasilającej się współpracy Ujgurów z islamskimi ekstremistami można uznać opublikowane przez Państwo Islamskie nagranie, w którym Ujgurzy obiecują „rozlać krew jak rzeki” w odwecie za chińskie represje (Beitler, 2017). Jednak im bardziej stawiają oni czoło chińskiej polityce, tym w większym stopniu Pekin eliminuje niebezpieczeństwo rosnącego separatyzmu. Wizerunek Ujgura - terrorysty przy wzroście nastrojów islamofobicznych daje przyzwolenie na antyterrorystyczne represje. W 2015 r. skazano na karę 3 lat pozbawienia wolności prawnika Pu Zhiqiang za krytyke chińskiego rządu na portalu społecznościowym. W listopadzie tego samego roku zamordowano 28 osób oskarżonych o dokonanie zamachu w chińskiej kopalni węgla (w tym kobiety i dzieci spokrewnione z rzekomymi sprawcami). W marcu 2016 r. aresztowano pod zarzutem ekstremizmu religijnego 41 Ujgurów, a wśród nich lokalnych przywódców religijnych, którzy nie uczestniczyli w pogrzebie członka partii komunistycznej. W 2016 r. zaostrzono środki bezpieczeństwa na obszarze Xinjiangu. Decyzją komunistycznej partii zwiększono do 8 tysięcy liczbę stacjonujących funkcjonariuszy policji. Całodobowe patrole sprawdzają pochodzenie i karty identyfikacyjne obywateli, jak również dokumenty turystów. Mieszkańcy Xinjiangu podlegają konieczności wyrobienia „zielonej karty” w przypadku chęci opuszczenia miejsca zamieszkania (Beitler, 2017; China: Situation of Uyghurs, 2016, ss. 52-58).

Wymienione zdarzenia dokonywane zarówno z rąk Ujgurów, jak i chińskich służb bezpieczeństwa stanowią tylko ułamek przykładów wzajemnej przemocy. Istnieją jednak wiarygodne dane, które wyraźnie sygnalizują znacznie większą liczbę śmiertelnych ofiar antyterrorystycznej polityki Chin, czemu komunistyczna partia oficjalnie zaprzecza (według chińskiego sprawozdania w wyniku przeprowadzonych ataków terrorystycznych w 1990 r. zginęło 56 osób, zaś 2001 r. już 362. We wstępie dokumentu, jak również w dalszej jego części widnieją zupełnie różne wielkości. Można się zatem domyślić, że nie pozostają one zgodne ze stanem faktycznym. Co ciekawe, wśród ofiar ujgurskiego terroryzmu znalazły się również osoby „podpalone” oraz "zatrute”. China: Situation of Uyghurs, 2016, s. 58; Clarke, 2015).

\section{MECHANIZMY NAPĘDZAJĄCE KONFLIKT CHIŃSKO-UJGURSKI}

Nie ulega wątpliwości, że oprócz przyczyn etnicznych i tożsamościowych przedstawionych w niniejszej pracy mechanizmy napędzające konflikt chińsko-ujgurski pozostają o wiele bardziej złożone, często również dynamiczne. Współczesna polityka wobec Xinjiangu ma zatem charakter czysto pragmatyczny. Szczególnie istotne pozostaje położenie autonomicznego regionu w części starożytnego jedwabnego szlaku. Ostatnie doniesienia o jego rewitalizacji jeszcze bardziej uatrakcyjnią Xinjiang jako „bufor" i „brama” do Azji Środkowej. Nie bez wpływu na konflikt chińsko-ujgurski pozostaje zatem możliwość połączenia cywilizacji kontynentu eurazjatyckiego, a dodatkowo bliskie sąsiedztwo trzech imperialnych mocarstw. Kontrola Xinjiangu położonego na styku rywalizujących ze sobą sił stanowi dla Państwa Środka „pas stabilizacyjny”, chroniący państwo przed nadmiernym wpływem innych mocarstw w regionie. Wszystkie te elementy sprawiają, że jego stabilność oraz 
rozwój gospodarczy leży w strategicznym interesie Chińskiej Republiki Ludowej (Clarke, 2008, s. 90; Tukmadiyeva, 2013, s. 101).

Niegdyś osłaniający przed nomadami, Związkiem Sowieckim, później nowo powstałymi republikami postsowieckimi, wreszcie niestabilnym Afganistanem oddzielając państwo od "terroryzmu, separatyzmu, fundamentalizmu”, dziś odgrywa również znaczenie w polityce gospodarczej jako obszar tranzytowy w przesyle energii, surowców, maszyn czy produktów przemysłowych. Od 2001 r. do 2011 r. handel zagraniczny Xinjiang wzrósł od 1,8 do 22,8 mld dolarów. Największymi rynkami eksportowymi pozostają państwa Azji Centralnej - Kazachstan, Kirgistan, Tadżykistan. Dzięki geopolitycznemu położeniu Xinjiangu Chiny importują z Azji Centralnej ropę naftową, produkty mineralne, surowce chemiczne oraz metale. Rosnące zapotrzebowanie na surowce energetyczne czyni Xinjiang kluczowym ośrodkiem handlowym (Tukmadiyeva, 2013, ss. 99-103). Ponadto obszar ten obfituje w gaz ziemny, ropę naftową oraz pierwiastki ziem rzadkich, dlatego dzięki kontroli Xinjiangu Chińska Republika Ludowa może maksymalnie eksploatować teren. Od początku XXI w. realizuje projekty budowy rurociągów, którymi dostarcza surowce z zachodnich regionów do mało zasobnych wschodnich części kraju (Фролова, 2014, ss. 70-71). Strategiczne znaczenie Xinjiangu wiąże się również z umieszczeniem w obrębie autonomicznego terytorium poligonu Jop-Nur, stanowiącego miejsce jądrowych testów. W latach 1964-1996 w wyniku przeprowadzonych wybuchów zginęło kilkaset tysięcy osób. Można domniemać, że nieprzypadkowo wybrano właśnie ten region, aby promieniowanie jonizujące nie uderzało bezpośrednio w Hanów, lecz w prowincję ujgurską (Merali, 2009).

Oprócz determinantów ekonomicznych problem z uzyskaniem większej autonomii w regionie wynika z prowadzonej przez Chiny polityki integrującej państwo. Gdyby to wielkie mocarstwo pozwoliło na separacje Xinjiangu, rozbudziłoby podobne nastroje w 4 pozostałych regionach autonomicznych. Zatem stabilność Xinjiangu determinuje realizacje doktryny „jednych Chin" (Tukmadiyeva, 2013, s. 106).

Złożona sieć mechanizmów napędzających konflikt chińsko-ujgurski wykracza jednak poza determinanty wewnętrzne, dlatego warto również spojrzeć na interakcje zachodzące na arenie międzynarodowej. Zauważyć należy, że Xinjiang nie ma żadnego wyraźnego sojusznika, a społeczność międzynarodowa nie podejmuje rzeczywistych kroków, aby ukrócić medialną propagandę, zniekształcającą wizerunek Ujgura i oblicze chińskiej polityki. Bezpośrednie wsparcie dla zagrożonej mniejszości byłoby niekorzystne z uwagi na ekonomiczne sukcesy państw współpracujących z największą na świecie chińską gospodarką. Dlatego właśnie w przypadku stosunków amerykańsko-chińskich sprawa Xinjiangu nie pozostaje tak drażliwa, jak kwestia Tybetu. Powodem, dla którego Stany Zjednoczone wolą zachować większą neutralność wobec wydarzeń w tym regionie jest z jednej strony narastający ujgurski ekstremizm i walka USA z międzynarodowym terroryzmem, z drugiej zaś próba zachowania partnerskich relacji geostrategicznych. W związku z tym po manifestacjach z 2009 r. Barack Obama nawoływał Chiny do poszanowania praw człowieka bez wyraźnych ingerencji (Van Wie Davis, 2008).

Za jedyne państwo zdające się obecnie pozostawać ujgurskim sprzymierzeńcem można uznać Turcję. Tureckojęzycznej mniejszości mającej bliskie związki kulturowe i religijne ze spadkobiercą Imperium Osmańskiego chętnie oferuje się paszporty i dokumenty tożsamości, będące przepustką do opuszczenia Państwa Środka i stanowiące na terytorium Turcji przeciwwagę dla Kurdów. Jednak problem z tureckim zaangażowaniem polega na rosnącej współpracy gospodarczej z Chinami. Do 2020 r. wymiana handlowa pomiędzy krajami ma osiągnąć 100 mld dolarów, co niewątpliwie nie sprzyja napędzaniu wrogości 
w relacjach chińsko-tureckich*. Inną kwestią pozostaje sprawa tureckich możliwości państwo pozostaje za słabe, aby móc w realny sposób wywrzeć presję na Chinach, jednak wszelkie próby antytureckiej i antyislamskiej dyskryminacji mogą sprawić, że zmieni retorykę i zdecyduje się nakłonić do współpracy pozostałe państwa regionu o tureckim charakterze narodowym (Shan \& Chen, 2010).

Spory wpływ na konflikt chińsko-ujgurski ma działalność diaspory Ujgurów żyjących w państwach zachodnich, Turcji i Arabii Saudyjskiej oraz wspomnianym już Kazachstanie, Kirgistanie czy Uzbekistanie. Problem braku integracji oraz wzrostu nastrojów separatystycznych dotyczy przede wszystkim Kazachstanu, gdzie utworzyła się obecnie najliczniejsza diaspora. Ujgurzy cieszą się tam wolnością myśli oraz wyznania, dzięki czemu mogą rozwijać swoją kulturę i angażować się w działania polityczne na rzecz walki z Chinami. W efekcie konflikt "rozlewa się" poza sporne terytorium, zagrażając bezpieczeństwu państw przyjmujących (Мавлонова, 2015, ss. 169-173).

Brak perspektyw na znaczące wsparcie z zewnątrz skłania Ujgurów do wspomnianej już współpracy z islamskimi ekstremistami. W latach 80. i 90. spory odsetek turkijskojęzycznej mniejszości przebywał w Pakistanie i Afganistanie, część współpracowała z Madrassami z południowych Indii albo uczestniczyła w kampanii przeciw terroryzmowi, jeszcze inni weszli w szeregi afgańskich talibów czy Islamskiego Ruchu Uzbekistanu. Sam fakt dzielenia granic z pięcioma państwami muzułmańskimi (Kazachstanem, Tadżykistanem, Kirgistanem, Afganistanem i Pakistanem) sprawia, że Ujgurzy, nieposiadający innych zwolenników, mogą szukać religijnych sprzymierzeńców wśród terrorystów (Bhattacharji, 2012). W związku z tym sytuacja Xinjiangu zależy w dużej mierze od pozostałych państw w regionie i ich stabilizacji. Zdaniem Stephena Fredericka Starra:

Choć przesadą jest powiedzieć, że zewnętrzne wpływy definiują Xinjiang, trudno jest znaleźć inny region, na który konsekwentnie wywierane były tak bardzo zróżnicowane zewnętrzne siły kulturowe. Wspólnie działają jak zewnętrzne pola grawitacyjne, ciągnąc za sobą Xinjiang w różnych kierunkach (...) (Starr, 2004, cyt. za Glen, 2015, s. 7).

\section{UWAGI KOŃCOWE}

Zmiany, które zachodzą w największym autonomicznym regionie Chin Sinciang-Ujgur ingerują nie tylko we współczesne życie Ujgurów, lecz także implikują negatywne zjawiska na przyszłość. Cechy „ograniczoności i nieodwracalności” dziedzictwa kulturowego sprawiają, że tradycyjna kultura ujgurska poddawana „asymilacji przez rozwój” może ulec bezpowrotnemu zatarciu wśród wytworów chińskiej cywilizacji. Problem żywotności korzeni etnicznych Ujgurów polega na tym, że mniejszość, która dopiero krystalizuje swoją samoświadomość dodatkowo walczy z niesprzyjającymi warunkami ochrony dziedzictwa. Najbardziej jednak niepokoi brak możliwości rozwoju kultury oraz wypracowywania nowych form i metod jej istnienia, które zagwarantowałyby przetrwanie (Джалилов, b.d.).

Zdaniem Albiny Achmetowej istnieją w przyszłości trzy możliwe trajektorie konfliktu:

\section{-....}

W 2015 r. w Turcji miały miejsce protesty zorganizowane przez tureckich muzułmanów i Ujgurów przeciwko rzekomemu zmuszaniu Ujgurów do spożywania posiłków w czasie muzułmańskiego miesiąca postu Ramadan (Wong, 2015). 
1. Dalsza sytuacja Ujgurów nie ulegnie zmianie, a Chińska Republika Ludowa będzie uporczywie represjonować mniejszość, niszczyć jej architektoniczne dziedzictwo, a także wykluczać wszelkie przejawy kulturowego rozwoju w celu zachowania stabilności.

2. Jakość życia Ujgurów w Xinjiangu ulegnie pogorszeniu. Taki scenariusz jest możliwy zarówno poprzez wewnętrzne uwarunkowania, m.in. zaostrzoną chińską dyskryminację mniejszości etnicznych, jak również zewnętrzne - zwycięstwo sił ekstremistycznych w regionie może doprowadzić do zamknięcia chińskiej granicy z Xinjiangiem, aby ochronić Państwo Środka przed radykalnymi siłami.

3. Chińska Republika Ludowa zwiększy autonomię Xinjiangu, lecz tylko w przypadku znaczącego osłabienia państwa, np. powstałe napięcia w Tybecie czy Mongolii Wewnętrznej mogłyby wpłynąć na pozostałe regiony bądź gdy społeczność międzynarodowa wywarłaby silną presję na Chinach w celu wsparcia ujgurskiej niezależności (Ахметова, 2013, s. 236).

Bez względu na to, jakie będą dalsze losy Xinjiangu, w każdym z trzech opisanych scenariuszy pozycja Ujgurów zależy od decyzji politycznych i społecznych wielkiego mocarstwa - Chińskiej Republiki Ludowej, dlatego błędem byłoby bagatelizowanie trwającego kryzysu. Ujgurzy wydają się nie być na tyle zorganizowani, aby przeciwstawić się Chińskiej Republice Ludowej, lecz samo umiędzynarodowienie konfliktu oraz dalsza radykalizacja ekstremistycznych bojowników może znacznie osłabić gospodarczą pozycję Chin w Azji Centralnej, odsuwając to państwo od korytarza energetycznego i handlowego. Pekin powinien zdać sobie zatem sprawę, że jego polityka dyskryminacyjna stanowi "pożywkę" dla rozwijającego się radykalnego islamu.

\section{BIBLIOGRAFIA}

Bachulska, A. (2015). Polityczny islam a problem ujgurski - implikacje chińskiej wojny z terroryzmem. Pobrano 4 sierpnia 2017, z http://peoplessquare.pl/2015/12/23/polityczny-islam-a-problem-ujgurski-implikacje-chinskiej-wojny-z-terroryzmem/

Bazylow, L. (1981). Historia Mongolii. Wrocław: Zakład Narodowy im. Ossolińskich.

Beitler, R. (2017, kwiecień 3). China's Islamophobia: Uighur Muslims, authoritarianism and worldwide fear. Pobrano 4 sierpnia 2017, z https://www.pastemagazine.com/articles/2017/04/chinas-islamophobia-uighur-muslims-authoritarianis.html

Bhattacharji, P. (2012, maj 29). Uighurs and China's Xinjiang Region. Pobrano 4 sierpnia 2017, z https://www.cfr.org/backgrounder/uighurs-and-chinas-xinjiang-region

Bovingdon, G. (2010). The Uyghurs - strangers in their own land. New York, NY: Columbia University Press.

Campbell, C. (2016, lipiec 21). Uighurs joining ISIS poses security problems for China. Time. Pobrano 4 sierpnia 2017, z http://time.com/4416585/isis-islamic-state-chinaxinjiang-uighur-xi-jinping/

China's changing strategic concerns: the impact on human rights in Xinjiang: roundtable before the Congressional-Executive Commission on China. One Hundred Ninth Congress. First session. By Frederick Starr. (2005, listopad 16). Pobrano 4 sierpnia 2017, z https://www.cecc.gov/events/roundtables/chinas-changing-strategic-concerns-theimpact-on-human-rights-in-xinjiang 
China says to increase police in Xinjiang for stability. (2012, styczeń 30). Pobrano 4 sierpnia 2017, z https://uyghuramerican.org/article/china-says-increase-police-xinjiang-stability.html

China: Situation of Uyghurs. (2016, kwiecień). COI Compilation. Pobrano 4 sierpnia 2017, z http://www.ecoi.net/file_upload/90_1462195747_accord-2016-04-china-uyghurs.pdf

Clarke, M. (2008). China's integration of Xinjiang with Central Asia: Securing a "Silk Road" to Great Power Status? China and Eurasia Forum Quarterly, 6(2).

Clarke, M. (2015). China and the Uyghurs: The „Palestinization” of Xinjiang? Middle East Policy, 22(3). Pobrano 4 sierpnia 2017, z http://mepc.org/china-and-uyghurs-palestinization-xinjiang

Congressional-Executive Commission on China. (2006). Roundtable before the Congressional-Executive commission on China one hundred ninth congress first session

Finley, J. S. (2013). The art of symbolic resistance: Uyghur identities and Uyghur-Han relations in contemporary Xinjiang. Leiden: Brill. https://doi.org/10.1163/9789004256781

Gil, A. (2016). Kwestia ujgurska w Chinach. W A. Szabaciuk, D. Wybranowski, \& R. Zenderowski (Red.), Religia w konfliktach etnicznych we współczesnym świecie: T. 2. Afryka i Azja. Lublin: Wydawnictwo KUL.

Glen, S. (2015). Sources of conflict in the Xinjiang Uyghur Autonomous Region: History, power, and Uyghur identity flux? Griffith Asia Quarterly, 3(1).

Hamut, B., \& Joniak-Lüthi, A. (2015). The language choices and script debates among the Uyghur in Xinjiang Uyghur Autonomous Region, China. Linguistik online, 70(1).

Hudayar, S. (2017, luty 13). Contemporary colonialism: The Uyghurs versus China. Pobrano 4 sierpnia 2017, z https://intercontinentalcry.org/contemporary-colonialism-uyghurs -versus-china/

Kamberi, D. (2005, maj). Uyghurs and Uyghur identity. Sino-Platonic Papers, 2005(150).

Kamberi, D. (2015). Uyghurs and Uyghur identity. Radio Free Asia. Pobrano 4 sierpnia 2017, z https://www.rfa.org/english/bookshelf/Uyghurldentity.pdf

Kobyliński, Z. (2011). Czym jest, komu jest potrzebne i do kogo należy dziedzictwo kulturowe? Mazowsze: Studia Regionalne, 2011(7).

magda. (2010, wrzesień 4). Znikajace miasta Ujgurow. Pobrano 4 sierpnia 2017, z https:// mingxinpian.wordpress.com/2010/09/04/znikajace-miasta-ujgurow/

Merali, Z. (2009, lipiec 1). Did China's nuclear tests kill thousands and doom future generations? Radioactive clouds hung over villagers as China detonated nuclear bombs in the air for four decades. Pobrano 4 sierpnia 2017, z https://www.scientificamerican. com/article/did-chinas-nuclear-tests/

Olechowski, A. (2012). Czy separatyści ujgurscy mogą zagrozić bezpieczeństwu Europy? W A. Moroska-Bonkiewicz (Red.), Ekstremizm polityczny we współczesnym świecie. Wrocław: Dolnośląska Szkoła Wyższa Edukacji.

Phillips, T. (2016, sierpień 30). Suicide bomber attacks Chinese embassy in Kyrgyzstan. The Guardian. Pobrano 4 sierpnia 2017, z http://www.theguardian.com/world/2016/ aug/30/bomb-attack-chinese-embassy-kyrgyzstan-bishkek

Repetowicz, W. (2015). Gdzie są granice tureckiego nacjonalizmu? Atak terrorystyczny "Szarych Wilków” w Bangkoku. Pobrano 4 sierpnia 2017, z http://www.defence24. pl/254045,gdzie-sa-granice-tureckiego-nacjonalizmu-atak-terrorystyczny-szarych-wilkow-w-bangkoku

Rezolucja Parlamentu Europejskiego z dnia 10 marca 2011 roku w sprawie sytuacji i dziedzictwa kulturowego w Kaszgaru. (2011). Pobrano 4 sierpnia 2017, z http://www. 
uyghurcongress.org/de/wp-content/uploads/2011/03/Angenommene-Texte-Donnerstag-10.-März-2011-Lage-und-Kulturerbe-in-Kashgar.pdf

Shan, W., \& Chen, G. (2009). The Urumqi riots and China's ethnic policy in Xinjiang. East Asian Policy, 2009(1/3).

Shan, W., \& Chen, G. (2010). China's new policy in Xinjiang and its challenges. East Asian Policy, 2010(2/3)

Starr, S. F. (2004). Introduction. W F. S. Starr (Red.), Xinjiang: China's Muslim borderland. New York, NY: Sharpe.

Szyszlak, T. (2012). Czynnik religijny w konfliktach etnicznych na przykładzie konfliktu chińsko - ujgurskiego. Zeszyty Naukowe WSOWL, 2012(2(164)).

Tohti, I. (2015, kwiecień 22). Present - day ethnic problems in Xinjiang Uighur Autonomous Region: Overview and recommendations (1) - unemployment. Pobrano 4 sierpnia 2017, z https://chinachange.org/tag/ethnic-descrimination/

Tukmadiyeva, M. (2013). Xinjiang in China's foreign policy toward Central Asia. The Quarterly Journal, 12(3). Pobrano 4 sierpnia 2017, z http://hkmb.hktdc.com/en/1X09QAJN/ hktdc-research/Xinjiang-gateway-to-Central-Asia\%E2\%80\%99s-markets

Tyler, C. (2004). Wild West China: The taming of Xinjiang. New Brunswick, NJ: Rutgers University Press.

Uighur exiles confirm deaths in China clash. (2014, lipiec 30). Pobrano 4 sierpnia 2017, z https://www.aljazeera.com/news/asia-pacific/2014/07/uighur-exiles-confirm-deathschina-clash-20147304540673666.html

Uyghur language under attack: The myth of "bilingual" education in the People's Republic of China. (2007, lipiec 24). Uyghur Human Rights Project. Pobrano 4 sierpnia 2017, z http://docs.uyghuramerican.org/UyghurLanguageUnderAttack.pdf

Van Wie Davis, E. (2008, styczeń). Uyghur Muslim ethnic separatism in Xinjiang, China. Pobrano 4 sierpnia 2017, z http://apcss.org/college/publications/uyghur-muslim-ethnicseparatism-in-xinjiang-china/

Weiwen, Y. (2014). The natural resource curse in Xinjiang. Pobrano 4 sierpnia 2017, z http:// www.pp.u-tokyo.ac.jp/graspp-old/courses/2014/documents/graspp2014-5140143-2a.pdf

Wong, E. (2015, lipiec 28). Ethnic tensions in Xinjiang complicate China-Turkey ties. The New York Times. Pobrano 4 sierpnia 2017, z https://www.nytimes.com/2015/07/29/ world/asia/ethnic-tensions-in-xinjiang-complicate-china-turkey-ties.html

Wieczorek, P. (2015). Konflikt w Ujgurskim Autonomicznym Regionie Xinjiang i jego wpływ na bezpieczeństwo w regionie. Wschodnioznawstwo, 2015(1).

Wu, E. (2006, luty 2). Putonghua push in Uygur nursery schools. South China Morning Post. Pobrano 4 sierpnia 2017, z http://uyghuramerican.org/old/articles/193/1/ Putonghua-push-in-Uygur-nursery-schools/Putonghua-push-in-Uygur-nursery-schools. html

Ануфриев, К. С. (2013). Эволюция политики цинского Китая в Центральной Азии. Вестник Томского государственного университета: История, 2013(1).

Ахметова, А. Р. (2013). Этнические проблемы Китая (на примере Синьцзян-Уйгурского автономного района). Pobrano 4 sierpnia 2017, z http://enu.kz/repository/repository2012/etnicheskie-problemy.pdf

Дергачев, В. (b.d.). Возрождение Синьцзяна. Pobrano 4 sierpnia 2017, z http://dergachev. ru/Landscapes-of-life/Xinjiang/

Джалилов, Г. (b.d.). Традиции и современность в духовной культуре уйгуров СУАРa. Pobrano 4 sierpnia 2017, z http://uighur.narod.ru/uigur2/article22.html 
Мавлонова, А. С. (2015). Роль уйгурской диаспоры за рубежом в борьбе за независимость Синьцзяна. Вестник РуДН: Серия "Международные отношения", 2015(3).

Турсун, H. (b.d.). Вопросы этногенеза уйгуров в китайской историографии. Pobrano 4 sierpnia 2017, z http://www.knyazev.org/biblio/Nabidjan\%20Tursun.pdf

Фролова, И. Ю. (2014). Экономическая политика КНР в Синьцзян-Уйгурском автономном районе в контексте интересов стран Центральной Азии. Международная Политика: Проблемы национальной стратегии, 2014(4(25)).

Ротарь, И. (2011). Необычный Китай. Путевые заметки из Синьцзян-Уйгурского автономного района. Pobrano 8 sierpnia 2017, z http://www.fergananews.com/articles/6936

\section{BIBLIOGRAPHY (TRANSLITERATION)}

Akhmetova, A. R. (2013). Étnicheskie problemy Kitaia (na primere Sin'tszian-Uigurskogo avtonomnogo raĭona). Retrieved August 4, 2017, from http://enu.kz/repository/repository2012/etnicheskie-problemy.pdf

Anufriev, K. S. (2013). Ėvoliutsiia politiki tsinskogo Kitaia v TSentral'noĭ Azii. Vestnik Tomskogo gosudarstvennogo universiteta: Istoriia, 2013(1).

Bachulska, A. (2015). Polityczny islam a problem ujgurski - implikacje chińskiej wojny z terroryzmem. Retrieved August 4, 2017, from http://peoplessquare.pl/2015/12/23/ polityczny-islam-a-problem-ujgurski-implikacje-chinskiej-wojny-z-terroryzmem/

Bazylow, L. (1981). Historia Mongolii. Wrocław: Zakład Narodowy im. Ossolińskich.

Beitler, R. (2017, April 3). China's Islamophobia: Uighur Muslims, authoritarianism and worldwide fear. Retrieved August 4, 2017, from https://www. pastemagazine.com/articles/2017/04/chinas-islamophobia-uighur-muslims-authoritarianis.html

Bhattacharji, P. (2012, May 29). Uighurs and China's Xinjiang Region. Retrieved August 4, 2017, from https://www.cfr.org/backgrounder/uighurs-and-chinas-xinjiang-region

Bovingdon, G. (2010). The Uyghurs - strangers in their own land. New York, NY: Columbia University Press.

Campbell, C. (2016, July 21). Uighurs joining ISIS poses security problems for China. Time. Retrieved August 4, 2017, from http://time.com/4416585/isis-islamic-state-china -xinjiang-uighur-xi-jinping/

China's changing strategic concerns: the impact on human rights in Xinjiang: roundtable before the Congressional-Executive Commission on China. One Hundred Ninth Congress. First session. By Frederick Starr. (2005, November 16). Retrieved August 4, 2017, from https://www.cecc.gov/events/roundtables/chinas-changing-strategic-concerns-the-impact-on-human-rights-in-xinjiang

China says to increase police in Xinjiang for stability. (2012, January 30). Retrieved August 4, 2017, from https://uyghuramerican.org/article/china-says-increase-police-xinjiang -stability.html

China: Situation of Uyghurs. (2016, April). COI Compilation. Retrieved August 4, 2017, from http://www.ecoi.net/file_upload/90_1462195747_accord-2016-04-china-uyghurs.pdf

Clarke, M. (2008). China's integration of Xinjiang with Central Asia: Securing a "Silk Road" to Great Power Status? China and Eurasia Forum Quarterly, 6(2).

Clarke, M. (2015). China and the Uyghurs: The "Palestinization" of Xinjiang? Middle East Policy, 22(3). Retrieved August 4, 2017, from http://mepc.org/china-and-uyghurs-palestinization-xinjiang 
Dergachev, V. (n.d.). Vozrozhdenie Sin'tsziana. Retrieved August 4, 2017, from http://dergachev.ru/Landscapes-of-life/Xinjiang/

Dzhalilov, G. (n.d.). Traditsii i sovremennost' v dukhovnoĭ kul'ture uĭgurov SUARa. Retrieved August 4, 2017, from http://uighur.narod.ru/uigur2/article22.html

Finley, J. S. (2013). The art of symbolic resistance: Uyghur identities and Uyghur-Han relations in contemporary Xinjiang. Leiden: Brill. https://doi.org/10.1163/9789004256781

Frolova, I. I. (2014). Ėkonomicheskaia politika KNR v Sin'tszian-Uigurskom avtonomnom raĭone v kontekste interesov stran TSentral'nol̆ Azii. Mezhdunarodnaia Politika: Problemy natsional' noi strategii, 2014(4(25)).

Gil, A. (2016). Kwestia ujgurska w Chinach. In A. Szabaciuk, D. Wybranowski, \& R. Zenderowski (Eds.), Religia w konfliktach etnicznych we współczesnym świecie: Vol. 2. Afryka i Azja. Lublin: Wydawnictwo KUL.

Glen, S. (2015). Sources of conflict in the Xinjiang Uyghur Autonomous Region: History, power, and Uyghur identity flux? Griffith Asia Quarterly, 3(1).

Hamut, B., \& Joniak-Lüthi, A. (2015). The language choices and script debates among the Uyghur in Xinjiang Uyghur Autonomous Region, China. Linguistik online, 70(1).

Hudayar, S. (2017, February 13). Contemporary colonialism: The Uyghurs versus China. Retrieved August 4, 2017, from https://intercontinentalcry.org/contemporary-colonialism-uyghurs-versus-china/

Kamberi, D. (2005, May). Uyghurs and Uyghur identity. Sino-Platonic Papers, 2005(150).

Kamberi, D. (2015). Uyghurs and Uyghur identity. Radio Free Asia. Retrieved August 4, 2017, from https://www.rfa.org/english/bookshelf/Uyghurldentity.pdf

Kobyliński, Z. (2011). Czym jest, komu jest potrzebne i do kogo należy dziedzictwo kulturowe? Mazowsze: Studia Regionalne, 2011(7).

magda. (2010, September 4). Znikajace miasta Ujgurow. Retrieved August 4, 2017, from https://mingxinpian.wordpress.com/2010/09/04/znikajace-miasta-ujgurow/

Mavlonova, A. S. (2015). Rol' uĭgurskoì diaspory za rubezhom v bor'be za nezavisimost' Sin'tsziana. Vestnik RUDN: Seriia "Mezhdunarodnye otnosheniia", 2015(3).

Merali, Z. (2009, July 1). Did China's nuclear tests kill thousands and doom future generations? Radioactive clouds hung over villagers as China detonated nuclear bombs in the air for four decades. Retrieved August 4, 2017, from https://www.scientificamerican. com/article/did-chinas-nuclear-tests/

Olechowski, A. (2012). Czy separatyści ujgurscy mogą zagrozić bezpieczeństwu Europy? In A. Moroska-Bonkiewicz (Ed.), Ekstremizm polityczny we współczesnym świecie. Wrocław: Dolnośląska Szkoła Wyższa Edukacji.

Phillips, T. (2016, August 30). Suicide bomber attacks Chinese embassy in Kyrgyzstan. The Guardian. Retrieved August 4, 2017, from http://www.theguardian.com/ world/2016/aug/30/bomb-attack-chinese-embassy-kyrgyzstan-bishkek

Repetowicz, W. (2015). Gdzie są granice tureckiego nacjonalizmu? Atak terrorystyczny "Szarych Wilków" w Bangkoku. Retrieved August 4, 2017, from http://www.defence24.pl/254045,gdzie-sa-granice-tureckiego-nacjonalizmu-atak-terrorystyczny-szarychwilkow-w-bangkoku

Rezolucja Parlamentu Europejskiego z dnia 10 marca 2011 roku w sprawie sytuacji i dziedzictwa kulturowego w Kaszgaru. (2011). Retrieved August 4, 2017, from http://www. uyghurcongress.org/de/wp-content/uploads/2011/03/Angenommene-Texte-Donnerstag-10.-März-2011-Lage-und-Kulturerbe-in-Kashgar.pdf 
Rotar, I. (2011). Nieobycznyjkitaj. Putiewyje zamietki iz Sin'czian-Ujgurskogo awtonomnogo rajona. Retrieved August 8, 2017, from http://www.fergananews.com/articles/6936 Shan, W., \& Chen, G. (2009). The Urumqi riots and China's ethnic policy in Xinjiang. East Asian Policy, 2009(1/3).

Shan, W., \& Chen, G. (2010). China's new policy in Xinjiang and its challenges. East Asian Policy, 2010(2/3).

Starr, S. F. (2004). Introduction. In F. S. Starr (Ed.), Xinjiang: China's Muslim borderland. New York, NY: Sharpe.

Szyszlak, T. (2012). Czynnik religijny w konfliktach etnicznych na przykładzie konfliktu chińsko - ujgurskiego. Zeszyty Naukowe WSOWL, 2012(2(164)).

Tohti, I. (2015, April 22). Present - day ethnic problems in Xinjiang Uighur Autonomous Region: Overview and recommendations (1) - unemployment. Retrieved August 4, 2017, from https://chinachange.org/tag/ethnic-descrimination/

Tukmadiyeva, M. (2013). Xinjiang in China's foreign policy toward Central Asia. The Quarterly Journal, 12(3). Retrieved August 4, 2017, from http://hkmb.hktdc.com/ en/1X09QAJN/hktdc-research/Xinjiang-gateway-to-Central-Asia\% E2\% 80\%99s-markets

Tursun, N. (n.d.). Voprosy ètnogeneza uĭgurov v kitaǐskoĭ istoriografii. Retrieved August 4, 2017, from http://www.knyazev.org/biblio/Nabidjan\%20Tursun.pdf

Tyler, C. (2004). Wild West China: The taming of Xinjiang. New Brunswick, NJ: Rutgers University Press.

Uighur exiles confirm deaths in China clash. (2014, July 30). Retrieved August 4, 2017, from https://www.aljazeera.com/news/asia-pacific/2014/07/uighur-exiles-confirm-deaths-china-clash-20147304540673666.html

Uyghur language under attack: The myth of "bilingual" education in the People's Republic of China. (2007, July 24). Uyghur Human Rights Project. Retrieved August 4, 2017, from http://docs.uyghuramerican.org/UyghurLanguageUnderAttack.pdf

Van Wie Davis, E. (2008, January). Uyghur Muslim ethnic separatism in Xinjiang, China. Retrieved August 4, 2017, from http://apcss.org/college/publications/uyghur-muslimethnic-separatism-in-xinjiang-china/

Weiwen, Y. (2014). The natural resource curse in Xinjiang. Retrieved August 4, 2017, from http://www.pp.u-tokyo.ac.jp/graspp-old/courses/2014/documents/graspp2014-51401432a.pdf

Wieczorek, P. (2015). Konflikt w Ujgurskim Autonomicznym Regionie Xinjiang i jego wpływ na bezpieczeństwo w regionie. Wschodnioznawstwo, 2015(1).

Wong, E. (2015, July 28). Ethnic tensions in Xinjiang complicate China-Turkey ties. The New York Times. Retrieved August 4, 2017, from https://www.nytimes. com/2015/07/29/world/asia/ethnic-tensions-in-xinjiang-complicate-china-turkey-ties.html

Wu, E. (2006, February 2). Putonghua push in Uygur nursery schools. South China Morning Post. Retrieved August 4, 2017, from http://uyghuramerican.org/old/articles/193/1/Putonghua-push-in-Uygur-nursery-schools/Putonghua-push-in-Uygur-nurseryschools.html 